\title{
PROFIL KEMAMPUAN BERPIKIR KREATIF SISWA KELAS X SMK NEGERI 7 ENDE
}

Simplisia Mako ${ }^{1}$, Aloisius Harso ${ }^{2}$, dan Melkyanus Kaleka ${ }^{3}$

1,2,3 Pendidikan Fisika Universitas Flores, Nusa Tengggara Timur, Indonesia

Coreresponding author email: simplisia.mako@gmail.com

\author{
Info Artikel \\ Diterima: \\ 19 September 2020 \\ Disetujui: \\ 3 Desember 2020 \\ Dipublikasikan: \\ 15 Desember 2020
}

\begin{abstract}
Abstrak:
Penelitian ini bertujuan untuk mendeskripsikan profil kemampuan berpikir kreatif kelas X SMK Negeri 7 Ende. Jenis penelitian adalah penelitian deskriptif. Subjek penelitian yaitu siswa kelas X AP yang berjumlah 23 orang. Data yang diperoleh berupa nilai hasil tes kemampuan berpikir kreatif. Data dianalisis secara deskriptif. Hasil penelitian menunjukan bahwa kemampuan berpikir kreatif untuk semua indikator di peroleh rata-rata 90,2\% dengan kategori sangat kreatif. Kemampuan berpikir kreatif yang diteliti meliputi berpikir luwes, lancar, original, merinci dan mengevaluasi.
\end{abstract}

Kata kunci: Kemampuan, berpikir, kreatif

\begin{abstract}
:
This study aims to describe the profile of creative thinking skills in class X SMK Negeri 7 Ende. This type of research is descriptive research. The research subjects were students of class $X A P$, totaling 23 people. The data obtained are in the form of test scores for creative thinking skills. Data were analyzed descriptively. The results showed that the ability to think creatively for all indicators was obtained an average of $90.2 \%$ in the very creative category. The creative thinking skills studied include flexible, fluent, original thinking, detailing and evaluating.
\end{abstract}

Keywords: Creative, thinking, ability

Copyright @ 92020 Edufisika: Jurnal Pendidikan Fisika

\section{Pendahuluan}

Era globalisasi ditandai dengan fenomena-fenomena sosial dan terjadinya proses perubahan hubungan antar bangsa dan antar Negara, persaingan, pengaruh dan kemajuan ilmu pengetahuan dan teknologi (IPTEK), sehingga fenomena ini menuntut pendidikan setiap negara untuk menghasilkan lulusan-lulusan sumber daya manusia (SDM) yang memiliki kualitas dan integrasi disetiap disiplin keilmuan. Kebijakan kurikulum 2013 merupakan inovasi pendidikan, sebagai bagian dari kemajuan pemikiran bangsa dalam mewujudkan pendidikan, yang bermutu. Kebijakan kurikulum 2013 menawarkan konsep dan gagasan yang baru untuk merubah pendidikan menjadi lebih baik. Dengan adanya muatan kompetensi dan karakter yang terintergrasi dan dapat ditekan secara holistik diharapkan siswa mampu keluar dari kemelut persoalan yang menunjukan ketidak mampunya seperti yang selama dikelukan. Kebijakan kurikulum 2013 menuntut kita harus dapat meresponnya dengan kesungguhan dan semangat agar dapat melakukan perubahan dalam pembenaan pendidikan.

Berangkat dari itu Kurikulum dapat diartikan sebagai langkah kongkrit untuk menjemput impian pendidikan dalam memanusiakan manusia itu sendiri, dan kurikulum sebagai alat untuk 
membentuk watak dan sifat siswa. Didalam kurikulum terdapat aturan-aturan proses belajar dan mengajar. Kurikulum itu rencana pelajaran (plan for learning) yang di berikan kepada guru untuk diterapkan kepada siswa agar siswa bisa menjadi manusia yang terampil, inovatif, kreatif serta aktif dalam menjawab polemik berkehidupan (Nasution, 1994). Maka dapat kita simpulkan bahwa jika kurikulum tidak diberlakukan untuk kepentingan pendidikan, kurikulum dapat merancang semua pendidikan yang merangkum pengelaman belajar yang disediakan disekolah dan untuk siswa, rancangan ini dimaksud untuk memberikan pedoman kepada parapelaksana pendidikan dalam proses perkembangan pembimbingan belajar siswa yang sesuai dengan cita-cita dari siswa, keluarga dan masyarakat sekitar.

Perubahan dunia kini tengah memasuki era revolusi industri 4.0 atau revolusi industri dunia keempat di mana teknologi informasi telah menjadi basis dalam kehidupan manusia (Kemristekdikti, 2018). Untuk menghadapi era revolusi indutri 4.0, di perlukan pendidikan yang dapat membentuk generasi kreatif, salah satunya dapat mencapai dengan cara mengoptimalisasi pengguna teknologi sebagai alat bantu pendidikan yang diharapkan mampu menghasilkan output yang dapat mengikuti atau mengubah zaman menjadi lebih baik sehingga memiliki kemampuan untuk menciptakan ide atau gagasan baru yang di peroleh dari kemampuan berpikir kreatif.

Munandar (Marliani, 2015) menyatakan berpikir kreatif adalah kegiatan yang berdasarkan kesadaran yang menggabungkan berpikir logis dan berpikir divergen. Munandar (Rosa, 2016) berpikir divergen adalah memberikan macam-macam kemungkinan jawaban berdasarkan informasi yang diberikan dengan penekanan pada keragaman jumlah dan kesesuaian. Johnson (Rosa, 2016) berpikir kreatif ialah salah satu kebiasaan dari pikiran yang dilatih dengan memperhatikan intuisi, menghidupkan, imajinasi, mengungkapkan kemungkinan-kemungkinan baru, membuka sudut pandang yang menakjubkan, dan membangkitkan ide-ide yang tidak terduga. Berdasarkan Munandar (Susiningrum, 2018) dan Piaw (Elfiani, 2017) ada beberapa jenis kemampuan berpikir kreatif yaitu: (a) berpikir lancar (fluency) menyebabkan seorang mampu menemukan banyak gagasan, jawaban, penyelesaian masalah atau pertanyaan. (b) berpikir Luwes (flekxibiliti) dimana orang kreatif menghasilkan gagasan, jawaban, ataupun pertanyaan yang bervariasi karena dia mampu melihat masalah dari sudut pandang yang berbeda. (c) berpikir orisinil (originality) yang dapat mendorong orang kreatif dan dapat menemukan ungkapan yang baru dan unik, karena mereka sanggup memikirkan yang tidak lazim untuk mengungkapkan dirinya, mampu menemukan kombinasikombinasi yang tidak biasa dari unsur-unsur yang biasa dan (d) keterampilan mengelaborasi (elaboration) yang meliputi kemampuan memperkaya dan mengembangkan satu gagasan atau produk. Kemampuan berpikir kreatif sangat diperlukan saat pembelajaran fisika karena siswa dituntut untuk menemukan hal-hal yang baru, berpikir kreatif juga sangat diperlukan untuk memecahakan suatu permasalahan. Langkah-langkah dalam kemampuan berpikir kreatif (a) Tahap persiapan (preparation) (b) Tahap Inkubasi (Incubation) (c) Tahap Iluminasi (Iluminaton) (d) Tahap Verifikasi.

Kurikulum 2013 merupakan kurikulum berbasis kompetensi. Kurikulum berbasis kompetensi adalah "outcomes-based curriculum"oleh karena itu pengembangan kurikulum diarahkan pada pencapaian kompetensi yang dirumuskan dari SKL. Demikian pula penilaian hasil belajar dan hasil kurikulum diukur dari pencapaian kompetensi. Keberhasilan kurikulum dapat dartikan sebagai pencapaian kompetensi yang dirancang dalam suatu dokumen kurikulum oleh seluruh siswa

Undang-undang Nomor 20 Tahun 2003 tentang Sistem Pendidikan Nasional menyebutkan bahwa kurikulum merupakan seperangkat rencana dan pengaturan mengenai tujuan, isi dan bahan pelajaran serta cara yang digunakan sebagai pedoman untuk penyelenggaraan kegiatan pembelajaran agar dapat mencapai tujuan pendidikan tertentu. Berdasarkan pengertian tersebut, ada dua dimensi kurikulum, yang pertama adalah rencana dan pengaturan mengenai tujuan, isi, dan bahan pelajaran, sedangkan yang kedua adalah cara yang digunakan untuk kegiatan pembelajaran. Kurikulum yang diberlakukan mulai tahun ajaran 2013/2014 memenuhi kedua dimensi tersebut.

Kurikulum 2013 dirancang dengan berbagai karakteristik sebagai berikut: (a) Mengembangan keseimbanganantara pengembangan sikap spiritual dan sosial, rasa ingin tahu, kreativitas, kerja sama dengan kemampuan intelektual dan psikomotorik; (b) Sekolah merupakan bagian dari masyarakat yang memberikan pengalaman belajar terencana dimana peserta didik menerapkan apa yang dipelajari disekolah untuk masyarakat dan memanfaatkan masyarakat sebagai sumber belajar; (c) Mengembangkan sikap, pengetahuan dan keterampilan serta menerapkanya dalam berbagai situasi 
disekolah dan masyarakat; (d) Memberi waktu yang cukup leluasa untuk mengembangkan berbagai sikap, pengetahuan dan keterampilan; (e) Kompetensi dinyatakan dalam bentuk kompetensi inti kelas yang dirinci lebih lanjut dalam kompetensi dasar mata pelajaran; (f) Kompetensi kelas menjadi unsur pengorganisasi (organizing elements) kompetensi dasar, dimana semua kompetensi dasar dan proses pembelajaran dikembangkan untuk mencapai kompetensi yang dinyatakan dalam kompetensi inti; $(\mathrm{g})$ Kompetensi dasar dikembangkan didasarkan pada prinsip akumulatif, saling memperkuat (reinfirced) dan memperkaya (enriched) antar mata pelajaran dan jenjang pendidikan (organisasi horizontal dan vertical).

Dilihat dari pendekatan yang dilakukan dalam penyusunan Standar Kompetensi Lulusan (SKL) pada Kurikulum Berbasis Kompetensi (KBK) 2004 dan KTSP 2006, disimpulkan bahwa SKL dapat dirumuskan dari beberapa mata pelajaran yang telah ditetapkan terlebih dahulu. Ini berarti bahwa SKL satuan pendidikan ditetapkan dengan mengacu kepada mata pelajaran yang harus diajarkan kepada siswa, atau dengan kata lain mata pelajaran menjadi penentu rumusan SKL. Keberhasilan implementasikurikulum 2013 juga dapat dilihat dari indikator-indikator perubahan sebagai berikut (Awaliyah, 2014):

a. Adanya lulusan yang berkualitas, produktif, kreatif dan mandiri;

b. Adanya peningkatan mutu pembelajaran;

c. Adanya peningkatan efisiensi dan efektivitas pengelolaan dan pendayagunaan sumber belajar;

d. Adanya peningkatan perhatian serta partisipasi masyarakat.

e. Adanya peningkatan tanggung jawab sekolah;

f. Tumbuhnya sikap, keterampilan dan pengetahuan secara utuh di kalangan peserta didik;

g. Terwujudnya pembelajaran aktif, kreatif, efektif dan menyenangkan (PAKEM);

h. Terciptanya iklim yang aman, nyaman dan tertib, sehingga pembelajaran dapat berlangsung dengna tenang dan menyenangkan (joyfull learning);

i. Adanya proses evaluasi dan perbaikan secara berkelanjutan (continuous quality improvement)

Fungsi kurikulum secara umum adalah sebagai berikut: (a) Kurikulum merupakan alat untuk mencapai tujuan pendidikan nasional. (b) Kurikulum merupakan program yang harus dilaksanakan oleh guru dan murid dalam proses belajar mengajar, guna mencapai tujuan-tujuan itu. (c) Kurikulum merupakan pedoman guru dan siswa agar terlaksana proses belajar mengajar dengan baik dalam rangka mencapai tujuan pendidikan.

Kurikulum dan pendidikan adalah dua hal yang erat berkaitan, tak dapat dipisahkan satu dengan lain hubungan antara pendidikan dan kurikulum adalah hubungan tujuan dan isi pendidikan. Kurikulum merupakan kumpulan semua pengalaman belajar siswa, bahan, guru, prasasaran, masyarakat, sistem sekolah dan lain-lain. Kurikulum merupakan wujud materi yang diajarkan dalam proses pembelajaran di sekolah yang mencakup bidang-bidang inti yang bermuatan nasional maupun bidang tambahan yang bermuatan lokal. Kurikulum dalam sistem pendidikan modern memiliki peran sentral.

Berpikir merupakan suatu kegiatan mental yang dialami seorang bila mereka dihadapkan pada suatu masalah atau situasi yang harus dipecahkan. Proses berpikir dapat mewujudkan didalam dua bentuk yaitu proses berpikir tingkat tinggi dan proses berpikir tingkat rendah. Salah satu proses berpikir tingkat tinggi adalah berpikir kreatif, pada umumnya berpikir kreatif berhubungan dengan penemuan sesuatu, mengenai hal yang dapat menghasilkan sesuatu yang baru dengan menggunakan sesuatu yang telah ada.

Menurut pendapat Harriman, berpikir kreatif merupakan suatu pemikiran yang berusaha menciptakan gagasan yang baru. Berpikir kreatif dapat juga diartikan sebagai suatu kegiatan mental yang digunakan seseorang untuk membangun ide atau gagasan yang baru. Berpikir kreatif sering pula disebut berpikir divergen, yang artinya adalah memberikan berbagai macam kemungkinan jawaban dari pertanyaan yang sama. Pehkonen (Rosa, 2016). memandang berpikir kreatif sebagai salah satu kombinasi dari berpikir logis dan berpikir divergen yang didasarkan pada intuisi tetapi masih dalam kesadaran. Munandar (Susinigrum, 2018) menjelaskan berpikir kreatif merupakan kemampuan menemukan banyak kemungkinan jawaban terhadap suatu masalah, dimana penekanannya pada kuantitas, dan keberagaman jawaban pada suatu masalah. 
Dari beberapa pendapat dapat disimpulkan bahwa berpikir kreatif adalah sebuah kebiasaan dari pikiran yang dilatih intuisi, menghidupkan imajinasi, mengungkapkan kemungkinan baru dan membangkitkan ide-ide yang tidak terduga. Manusia yang kreatif selalu berusaha untuk memberi makna pada proses belajarnya. Salah satu hal untuk mendorong manusia untuk belajar adalah dengan adanya sifat kreatif dalam dirinya dan keinginan untuk maju. Penelitian ini bertujuan untuk mendeskripsikan profil kemampuan berpikir kreatif kelas X SMK Negeri 7 Ende. Indikator berpikir kreatif sebagai berikut:

a. Berpikir lancar (fluent thinking) atau kelancaran merupakan kemampuan memprokduksi banyak gagasan

b. Berpikir luwes (flexible thinking) atau kelenturan merupakan kemampuan untuk mengajukan berbagai pendekatan atau jalan berpikir kreatif

c. Berpikir orisinil (original thinking) merupakan kemampuan untuk melahirkan gagasan-gagasan asli sebagai pemikiran sendiri

d. Keterampilan mengelaborasi (elaboration ability) merupakan kemampuan untuk menguraikan sesuatu secara terperinci

e. Keterampilan mengevaluasi atau menilai merupakan menyimpulkan mengenai masalah yang dipecahkan

\section{Metode Penelitian}

Jenis penelitian ini adalah penelitian deskriptif. Penelitian ini dilaksanakan di SMK Negeri 7 Ende tahun pelajaran 2019/2020. Populasi dalam penelitian ini adalah seluruh siswa kelas X semester 2 SMK Negeri 7 Ende Tahun pelajaran 2019/2020 yang terdiri dari kelas X AP, kelas X UPW dan ATPH dengan jumlah siswa sebanyak 50 orang. Sampel dari penelitian ini adalah penerapan kurikulum 2013 dalam meningkatkan kemampuan berpikir kreatif siswa kelas X AP SMK Negeri 7 Ende dengan jumlah siswa 23 orang. Teknik pengambilan sampel yang digunakan adalah Purposive Sampling yaitu teknik pengambilan sampel dengan pertimbangan-pertimbangan tertentu. pertimbangan dalam pengambilan sampel ini yaitu siswa kelas X AP memiliki siswa yang paling banyak dibandingkan dengan kelas APTH dan UPW. Variabel-variabel penelitian ini yaitu kemampuan berpikir kreatif.

Pada penelitian ini teknik pengumpulan data yang diguanakan adalah metode tes. Tes sebagai alat penelitian merupakan pertanyaan-pertanyaan yang diberikan kepada siswa untuk mendapatkan jawaban dari siswa dalam bentuk lisan (tes lisan), dalam bentuk tulisan (tes tulisan), atau dalam bentuk perbuatan (tes tindakan).

Instrumen yang digunakan dalam penelitian ini adalah tes kemampuan berpikir kreatif yang berisi beberapa aspek dan indikator untuk menyaring data kemampuan siswa dalam kemampuan berpikir kreatif. Dalam penelitian ini, untuk validitas dan reliabilitas instrumen menggunakan professional judments expret, yang artinya sebelum instrumen dibagikan kepada siswa validitas instrumen tersebut telah diuji oleh validator ahli yaitu dosen dan analisis menggunakan tabel Gregory (Gregory, 2000).

Perhitungan validitas isi oleh 2 orang ahli menggunakan rumus sebagai berikut:

Keterangan:

$$
v_{c}=\frac{D}{A+B+C+D}
$$

Vc : Validasi Content

A : Kedua judges tidak setuju

B : Judges I setuju, judges II tidak setuju

C : Judges I tidak setuju, judges II setuju

D : Kedua judges setuju

Kriteria validasi isi:

$0,80-1,00=$ Validasi sangat tinggi

$0,60-0,79=$ Validitas isi tinggi

$0,40-0,59=$ validasi isi sedang

$0,20-0,39=$ validitas isi rendah 
Tabel 1. Matrik Uji Gregory

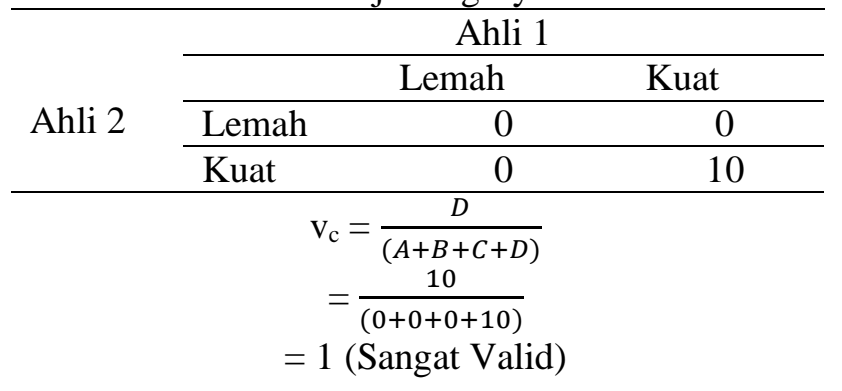

Dalam penelitian kuantitatif, analisis data adalah suatu kegiatan setelah data dari semua responden terkumpul. Dalam penelitian kuantitatif teknik analisis data yang digunakan sudah jelas, yaitu untuk menjawab rumusan masalah. Adapun rumus statistik yang digunakan dalam penelitian ini adalah sebagai berikut: Dalam penelitian ini teknik analisa data yang digunakan adalah statistik deskriptif. Statistik deskriptif adalah statistik yang digunakan untuk menganalisis data dengan cara mendeskripsikan atau mengambarkan data yang telah terkumpul sebagaimana adanya tampa bermaksud membuat kesimpulan yang berlaku untuk umum atau generalisasi. Dalam statistik deskriptif penyajian datanya antara lain melalui tabel, grafik, diagram lingkaran, pictogram, perhitungan modus, median, mean, desil, persentil, perhitungan penyebaran data melalui perhitungan rata-rata dan standar deviasi dan perhitungan presentase. (Sugiyono, 2009). Dalam penelitian ini analisis deskriptif digunakan untuk mendeskripsikan daa berupa rata-rata (mean), median, modus, skor maksimum, skor minimum, dari data kemampuan berpikir kreatif siswa dan data tersaji dalam diagram batang menggunakan microsoft word SPSS versi 22.0.

\section{Hasil Penelitian Dan Pembahasan}

Dalam analisis statistik deskriptif teknik yang digunakan berupa Rata-Rata (Mean), Median, Modus, Standar deviasi, Skor Minimum dan Skor Maksimum. Dapat dilihat pada tabel berikut.

Tabel 2. Nilai Rekapitulasi Data Perolehan Berpikir Kreatif

\begin{tabular}{cc}
\hline Statistik & Nilai \\
\hline Jumlah Siswa & 23 \\
\hline Nilai Tertinggi & 100 \\
\hline Nilai Terendah & 80 \\
\hline Mean & 85,66 \\
\hline Modus & 84 \\
\hline Median & 92 \\
\hline Standar Deviasi & 6,58 \\
\hline
\end{tabular}

Berdasarkan data kemampuan Berpikir Kreatif yang diolah, maka diperoleh ringkasan data seperti pada tabel berikut.

Tabel 3. Profil Kemampuan Berpikir Kreatif Siswa

\begin{tabular}{llc}
\hline Indikator kemampuan berpikir kreatif & Kategori & Persentase (\%) \\
\hline Berpikir Lancar & Sangat kreatif & $96 \%$ \\
\hline Berpikir Luwes & Sangat kreatif & $98 \%$ \\
\hline Berpikir Orosinil & Sangat kreatif & $87 \%$ \\
\hline Keterampilan merinci/mengelaborasi & Sangat kreatif & $82 \%$ \\
\hline
\end{tabular}


Berdasarkan hasil analisis data secara deskriptif menunjukan bahwa kemampuan berpikir kreatif siswa kelas X SMK Negeri 7 Ende berada pada level atau kategori yang sangat tinggi pada setiap aspek. Tingginya kemampuan berpikir kreatif siswa disebabkan oleh beberapa hal seperti: (1) berdasarkan hasil wawancara dengan guru dan kepala sekolah bahwa di SMK Negeri 7 Ende sudah menerapkan kurikulum 2013 dari tahun 2018. Pembelajaran pada kurikulum 2013 (K13), harus berkenaan dengan kesempatan yang diberikan kepada siswa untuk mengkonstruksi pengetahuannya, siswa perlu didorong untuk bekerja memecahkan masalah, menemukan segala sesuatu untuk dirinya, dan berupaya keras mewujudkan ide-idenya. Hasil penelitian ini konsisten dengan penelitian (Harso, Kwure, Ika; 2020) Hasil penelitian menunjukan bahwa terjadi peningkatan kreativitas sains siswa setelah menggunakan model pembelajaran generatif $\left(t_{\text {hitung }}=2,577, p>0,05\right)$ penelitian ini menyimpulkan bahwa model pembelajaran generatif mampu meningkatan kreativitas sains siswa di SMP. (2) dapat di tinjau dari RPP yang telah di laksanakan bahwa guru sudah menerapkan model pembelajaran discovery learning pada pembelajaran dikelas. Dengan menggunakan model pembelajaran discovery learning siswa akan dibimbing untuk mencari dan menemukan sendiri materi atau jawaban yang sedang dipelajari, aktivitas pembelajaran dimana materi disampaikan secara langsung kepada siswa dan siswa dianjurkan untuk mengolah materi tersebut secara mandiri. Hasil penelitian ini konsisten dengan penelitian (Tumurun, Gusrayani, Jayadinata; 2016) Pembelajaran dengan model discovery learning lebih mampu meningkatkan kemampuan berpikir kreatif siswa. Hal ini dapat dibuktikan dengan hasil perhitungan uji beda rata-rata gain pada kedua kelompok nilai sig (1-tailed) sebesar 0,001.

\section{Simpulan}

Berdasarkan hasil penelitian ini dapat disimpulkan bahwa kemampuan berpikir kreatif siswa di SMK Negeri 7 Ende semua indikator di peroleh rata-rata 90,2 \% dengan kategori sangat kreatif. Kemampuan berpikir kreatif yang diteliti meliputi berpikir luwes, lancar, original, merinci dan mengevaluasi.

\section{Referensi}

Fathur, Rohim, Susanto, H., \& Ellianawati. (2012). penerapan model discovery learning pada pembelajaran fisika untuk meningkatan kemapuan berpikir kreatif siswa. unnes physics education journal.

Harso, A., Kwure, K. k., \& Ika, Y. E. (2020). pengaruh model pr,belajaran generatif terhadap kreatifitas sains siswa kelas VIII smp swasta ilebura lewotobi. jurnal pendidikan fisika vol 4(1).

Hadma Yuliani, M. R. (2017). Keterampilan Berpikir Kreatif Pada Siswa Sekolah Menengah Di Palangka Raya Menggunakan Pendekatan Saintifik. Jurnal Pendidikan Fisika dan Keilmuan (JPFK) Vol 3 No 1, 48-56.

Hamid Nasrullah (2014) . Efektivitas Penerapan Kurikulum 2013 Terhadap Motivasi Belajar Siswa Kelas X Program Keahlian Teknik Kendaraan Ringan SMK Ma'arif 1 Kebumen . Skripsi Pendidikan Teknik Otomotif. FKIP, Universitas Muhammadiya Purworejo

Iru, La dan Arihi, La Ode Saifun. 2012. Pendekatan, metode, strategi dan model-model Pembelajaran

Jusi Aldeska (2018) . Analisis Penerapan Kurikulum 2013 Ditinjau Dari Standar Proses Pada Materi Fisika Kelas X Di Sma Yadika Natar

Lina Agustina. 2018. Efektivitas penerapan model pembelajaran dalam kurikulum 2013 di SMP Negeri 1 Delanggu. Jurnal pendidikan Biologi vol 15 No 1, 116-119

Profil Kemampuan Berpikir.... (Simplisia Mako, dkk) hal:124-130 
Makmur, dan Thahier, R. 2015. Inovasi Kreativitas Manusia. Makassar: PT Refika Aditama.

Marliani, N. (2015). Peningkatan Kemampuan Berpikir Kreatif Matematis Siswa Melalui Model Pembelajaran Missouri Mathematics Project (Mmp). Jurnal Formatif 5(1), 14-25.

Nike Sri Setiawati, D. D. (2018). Pengaruh Pendekatan Saintifik Terhadap Hasil Belajar Dalam Pembelajaran Ipa Di Sekolah Dasar. Jurnal Universitas Negeri Padang .

Novrita Mulya Rosa, A. P. (2016). Pengaruh Model Pembelajaran Berbasis Masalah Terhadap Kemampuan Berpikir Kritis Dan Kemampuan Berpikir Kreatif. Jurnal Formatif 6(3) , 175-183.

Rima Buana Prahastiwi, S. H. (2017). Penerapan Pendekatan Saintifik Untuk Meningkatkan Karakter Rasa Ingin Tahu Dan Prestasi Belajar Siswa Kelas X Mia 3 Sma Negeri 6 Malang. jurnal Universitas Negeri Malang.

Sani, R.A., (2017), Penilaian Autentik, Bumi Aksara, Jakarta.

Susiningrum, D. (Volume 06 Nomor 03 Tahun 2018). Pengembangan Instrumen Penilaian Kemampuan Berpikir Kreatif Pada Mata Pelajaran Ekonomi Kelas X SMA Hang Tuah 1 Surabaya. jurnal Fakultas Ekonomi, Universitas Negeri Surabaya

Sugiyono. (2007) metode penelitian kuantitatif, kualitatif dan R \& D Bandung: Alfabeta

Tumurun, G. J. (2016). pengaruh model pembelajaran discovery learning terhadap keterampilan berpikir kreatif siswa pada materi sifat-sifat cahaya. jurnal pena ilmiah vol 1, 1 . 